BMJ Open

Diabetes

Research

\& Care

\title{
Effectiveness, treatment durability, and treatment costs of canagliflozin and glucagon-like peptide-1 receptor agonists in patients with type 2 diabetes in the USA
}

\author{
Mukul Singhal, ${ }^{1}$ Hiangkiat Tan, ${ }^{1}$ Craig I Coleman, ${ }^{2}$ Michelle Han, ${ }^{3}$ Chi Nguyen, ${ }^{1}$ \\ Michael Ingham (iD) ${ }^{3}$
}

To cite: Singhal M, Tan H, Coleman $\mathrm{Cl}$, et al. Effectiveness, treatment durability, and treatment costs of canagliflozin and glucagon-like peptide-1 receptor agonists in patients with type 2 diabetes in the USA. BMJ Open Diab Res Care 2019;7:e000704. doi:10.1136/ bmjdrc-2019-000704

- Additional material is published online only. To view please visit the journal online (http://dx.doi.org/10.1136/ bmjdrc-2019-000704).

This study was presented, in part, in abstract form at the 78th Scientific Sessions of the American Diabetes Association from 22 to 26 June 2018 in Orlando, Florida.

Received 3 June 2019 Revised 18 September 2019 Accepted 24 September 2019

Check for updates

(c) Author(s) (or their employer(s)) 2019. Re-use permitted under CC BY-NC. No commercial re-use. See rights and permissions. Published by BMJ.

For numbered affiliations see end of article.

Correspondence to Mr Michael Ingham; mingham2@its.jnj.com

\section{ABSTRACT}

Introduction This real-world study compared glycemic effectiveness, treatment durability, and treatment costs with canagliflozin $300 \mathrm{mg}$ versus any dose of glucagon-like peptide-1 (GLP-1) receptor agonists in patients with type 2 diabetes mellitus (T2DM) in the USA.

Research design and methods A retrospective cohort study using administrative claims and laboratory data (1 April 2012 to 28 February 2017) from the HealthCore Integrated Research Database were used to assess mean $\mathrm{HbA} 1 \mathrm{c}$ at 3-month intervals, achievement of $\mathrm{HbA} 1 \mathrm{c}$ thresholds $(<7.0 \%,<8.0 \%,<9.0 \%)$, and treatment durability (ie, adherence, discontinuation, switching, treatment failure (ie, exceeding threshold $(7.0 \%, 8.0 \%$, $9.0 \%$ ), having a prescription for a new antihyperglycemic agent)) in adults with T2DM who initiated canagliflozin $300 \mathrm{mg}$ or any dose of a GLP-1 receptor agonist. Medication costs were calculated for adherent patients. Results There were no significant differences in the primary outcome of $\mathrm{HbA1c}$ levels at 3-month intervals ( $\leq 12$ months) in the canagliflozin $300 \mathrm{mg}$ versus any dose GLP-1 receptor agonist cohort. The likelihood of achieving $\mathrm{HbA} 1 \mathrm{c}<8.0 \%$ was not different $(\mathrm{p}=0.666)$, the likelihood of achieving $\mathrm{HbA1} c<7.0 \%$ was lower $(p=0.016)$, and the likelihood of achieving $\mathrm{HbA1} c<9.0 \%$ was higher $(\mathrm{p}=0.020)$ in the canagliflozin $300 \mathrm{mg}$ versus any dose GLP-1 receptor agonist cohort. The likelihood of treatment failure after reaching any $\mathrm{HbA1c}$ target was not different between cohorts. A higher proportion of patients were adherent to treatment $(p<0.0001)$ and a lower proportion discontinued $(p<0.0001)$ or switched medication $(p=0.023)$ in the canagliflozin $300 \mathrm{mg}$ versus any dose GLP-1 receptor agonist cohort. Over 1 year, medication costs were $\$ 1421$ $(p<0.001)$ lower with canagliflozin $300 \mathrm{mg}$ than any dose of GLP-1 receptor agonists.

Conclusions This real-world, US-based study found that initiation of canagliflozin $300 \mathrm{mg}$ versus any dose of a GLP-1 receptor agonist in patients with T2DM was not associated with significant differences in the primary outcome of $\mathrm{HbA1c}$ levels at 3-month intervals for up to 12 months after index, but showed better adherence, less discontinuation, and lower drug acquisition costs compared with initiation of any dose of a GLP-1 receptor agonist.

\section{Significance of this study}

What is already known about this subject?

- The glycemic efficacy of sodium glucose cotransporter 2 (SGLT2) inhibitors versus glucagon-like peptide-1 (GLP-1) receptor agonists has not been compared in head-to-head clinical trials of patients with type 2 diabetes mellitus (T2DM); previous realworld studies based on electronic medical records data have shown similar $\mathrm{HbA1C}$ reductions with the SGLT2 inhibitor canagliflozin and GLP-1 receptor agonists in patients with T2DM.

What are the new findings?

- After initiating canagliflozin $300 \mathrm{mg}$ versus any dose of a GLP-1 receptor agonist, there were no significant differences in mean $\mathrm{HbA1c}$ levels at 3-month intervals for up to 12 months (primary outcome), with similar or better achievement of $\mathrm{HbA} 1 \mathrm{C}<8.0 \%$ and $<9.0 \%$ and better adherence, less discontinuation, and lower drug acquisition costs when adherent.

How might these results change the focus of research or clinical practice?

- These findings provide comparative effectiveness data for canagliflozin $300 \mathrm{mg}$ versus any dose of a GLP-1 receptor agonist in the absence of headto-head clinical trial results and corroborate results from previous real-world studies.

\section{INTRODUCTION}

Managing hyperglycemia and cardiovascular risk are central to type 2 diabetes mellitus (T2DM) treatment and can help reduce the risk of diabetes-related morbidity and mortality. ${ }^{1}$ The Healthcare Effectiveness Data and Information Set (HEDIS) uses $\mathrm{HbA} 1 \mathrm{c}<8.0 \%$ as the cut-off for adequate glycemic control to measure quality metrics for many patients with T2DM and defines HbAlc $>9.0 \%$ as poor glycemic control. ${ }^{2}$ The American Diabetes Association (ADA) 
recommends a target HbA1c of $<7.0 \%$ for most adults and a less stringent target of $<8.0 \%$ for some populations, including those with a history of severe hypoglycemia. ${ }^{1}$

Treatment guidelines emphasize lifestyle modifications for all patients along with pharmacologic intervention to achieve glycemic control. ${ }^{13}$ Metformin is recommended in ADA and American Association of Clinical Endocrinologists/American College of Endocrinology (AACE/ACE) guidelines as the first-line treatment for T2DM unless it is contraindicated. The AACE/ACE guidelines recommend using one of the newer antihyperglycemic agents (AHAs), like a glucagon-like peptide-1 (GLP-1) receptor agonist, a sodium glucose co-transporter 2 (SGLT2) inhibitor, a dipeptidyl peptidase-4 (DPP-4) inhibitor, or, with caution, an older agent like a thiazolidinedione or sulfonylurea, as monotherapy in patients who cannot tolerate metformin or as dual therapy in patients with inadequate glycemic control on metformin alone. ${ }^{3}$ The ADA recommends the SGLT2 inhibitors canagliflozin and empagliflozin and the GLP-1 receptor agonist liraglutide as second-line therapy for patients with T2DM and cardiovascular disease, ${ }^{1}$ as these agents have been shown to reduce the risk of major adverse cardiovascular events (cardiovascular death, non-fatal myocardial infarction, or non-fatal stroke). ${ }^{4-6}$

No randomized controlled trial (RCT) has directly compared the efficacy of SGLT2 inhibitors versus GLP-1 receptor agonists in patients with T2DM, but metaanalyses and indirect treatment comparisons using RCT data suggest that reductions in HbAlc are similar with canagliflozin $300 \mathrm{mg}$ versus specific GLP-1 receptor agonists when used in combination with a variety of other AHAs (ie, metformin, metformin plus sulfonylurea, insulin). ${ }^{7-10}$ However, the effects of individual GLP-1 receptor agonists have not been differentiated in metaanalyses. Since the indirect comparisons of canagliflozin $300 \mathrm{mg}$ and GLP-1 receptor agonists were based on RCT data, there remained a need to further validate these results in real-world practice settings.

The aim of the present study was to compare glycemic effectiveness, treatment durability, and treatment costs in patients with T2DM initiated on an SGLT2 inhibitor (canagliflozin $300 \mathrm{mg}$ ) or any dose of a GLP-1 receptor agonist in the USA using both claims and laboratory results from the HealthCore Integrated Research Database (HIRD). This study specifically focused on canagliflozin $300 \mathrm{mg}$ and any dose of GLP-1 receptor agonists because selection of these agents may be influenced by treatment guidelines and because appropriate rigor could be applied for analysis of real-world outcomes using this comparison.

\section{METHODS}

\section{Data source}

Administrative claims data were retrieved from the HIRD, which contains fully adjudicated paid claims from the largest commercially insured population in the USA (over 45 million patients) and includes data from health maintenance organizations (HMO), preferred provider organizations (PPO), consumer-directed health plans (CDHP), Medicare Advantage plans, and indemnity plans. The HIRD also contains diagnostic laboratory testing results for about $33 \%$ of members receiving outpatient laboratory services from two large national reference laboratories. This observational study was exempt from informed consent stipulations as researchers accessed a limited data set without individual enrollee identifiers, and only summary statistics were reported. Data were accessed and used in compliance with the Health Insurance Portability and Accountability Act. HealthCore has in place a Data Use Agreement with the covered entities from which the data were used for this study (45 CFR 164.514(e)(4)(ii)). Data were in a Limited Data Set format (45 CFR 154.514(e) (2)).

\section{Study design and patient selection}

This retrospective administrative claims study compared patients initiating canagliflozin $300 \mathrm{mg}$ or any dose of a GLP-1 receptor agonist. Given the time frame for this study and relative launch dates for SGLT2 inhibitors, the decision to evaluate canagliflozin alone was based on the need to ensure sufficient sample size while clearly delineating individual SGLT2 inhibitor results; in addition, canagliflozin was suggested to be more effective than other SGLT2 inhibitors by a metaanalysis. ${ }^{11}$ The $300 \mathrm{mg}$ dose of canagliflozin was chosen for evaluation in this study based on its widespread real-world use as well as findings from prior real-world studies of canagliflozin versus GLP-1 receptor agonists. Sensitivity analysis of these prior studies has shown that patients initiated on canagliflozin $100 \mathrm{mg}$ had similar HbA1c levels over time compared with those initiated on canagliflozin $300 \mathrm{mg}^{12}{ }^{13}$; hence, for simplicity and additional rigor, only the $300 \mathrm{mg}$ dose of canagliflozin was used in this study. In addition, as individual GLP-1 receptor agonists have not been differentiated in metaanalyses, the comparison group included all GLP-1 receptor agonist use. The patient identification period ranged from 1 April 2013 through 28 February 2016. The study period (1 April 2012 through 28 February 2017) was chosen to allow 1 year of claims data before and after initiation of canagliflozin $300 \mathrm{mg}$ or any dose of a GLP-1 receptor agonist. The index date was defined as the date of the first prescription filled for canagliflozin $300 \mathrm{mg}$ or any dose of a GLP-1 receptor agonist (ie, liraglutide, dulaglutide, exenatide, lixisenatide, or albiglutide). Patients were followed for 12 months after the index date. Claims codes are listed in online supplementary table 1 .

Study eligibility criteria included $\geq 1$ medical claim with T2DM, identified by the International Classification of Diseases, Ninth/Tenth Revision (ICD-9/10) codes, during the entire study period; $\geq 1$ claim for canagliflozin $300 \mathrm{mg}$ or any dose of a GLP-1 receptor agonist; $\geq 1 \mathrm{HbA1c}$ laboratory value before and after the index 
date; $\geq 18$ years of age on the index date; and $\geq 12$ months of continuous health plan enrollment, including both medical and pharmacy coverage, both before and after the index date. Exclusion criteria included a diagnosis of type 1 diabetes, pregnancy or gestational diabetes, or steroid-induced diabetes; stage 3 or 4 chronic kidney disease, end-stage renal disease, renal transplant, or dialysis using ICD-9/10-Clinical Modification diagnosis/procedure codes and Current Procedural Terminology codes; and use of index or non-index medication in the baseline period (eg, SGLT2 inhibitor use in the GLP-1 receptor agonist cohort or canagliflozin $100 \mathrm{mg}$ or another SGLT2 inhibitor in the canagliflozin $300 \mathrm{mg}$ cohort). For patients who filled for both canagliflozin $300 \mathrm{mg}$ and any dose of a GLP-1 receptor agonist as their very first fill during the patient identification period, the first fill date for canagliflozin $300 \mathrm{mg}$ was defined as the index date, and canagliflozin $300 \mathrm{mg}$ was defined as the index medication.

\section{Baseline characteristics}

Demographic characteristics, including age, sex, region of residence, health plan type (ie, HMO, PPO, CDHP), and Medicare Advantage versus commercially insured, were reported during the 12-month baseline period. Clinical characteristics reported during the 12-month baseline period included HbAlc level, AHAs used, comorbidities, Elixhauser Comorbidity Index, ${ }^{14}$ Diabetes Complications Severity Index,${ }^{15}$ and specialty of prescribing physician.

\section{Outcomes}

The primary outcome was HbAlc level at 3-month intervals over 12 months for the overall population; HbAlc levels at 3-month intervals over 12 months were also reported for patients with baseline $\mathrm{HbAlc}$ between $7.0 \%$ and $<8.0 \%$, between $8.0 \%$ and $<9.0 \%$, and $\geq 9.0 \%$. The secondary outcomes included achievement of HbAlc levels below prespecified thresholds $(<8.0 \%$ (HEDIS quality measure), $<7.0 \%$ (ADA target), and $<9.0 \%$ ( $>9.0 \%$ is the HEDIS measure for poor glycemic control) ) among patients with a baseline value above the threshold and were analyzed using an intent-to-treat approach.

Secondary outcomes included (1) adherence, measured by the proportion of days covered (calculated as the total number of days the index medication was available divided by the total number of days in the follow-up period; proportion of days covered $\geq 80 \%$ was defined as adherent) ${ }^{16}$; (2) switching, defined as starting a non-index AHA medication not filled in the baseline period, within 60 days of the run-out date of the last prescription of the index medication (the date of the first non-index AHA medication was referred to as the switch date); (3) need for add-on therapy, defined as starting a non-index AHA medication within 60 days of a refill of the index medication; (4) treatment discontinuation, defined as failure to refill index medication within 90 days after the depletion of the previous days' supply (down-titration of canagliflozin $300 \mathrm{mg}$ to canagliflozin $100 \mathrm{mg}$ was not considered discontinuation); (5) treatment durability, including proportion of patients exceeding $\mathrm{HbAl} 1 \mathrm{c} \geq 7.0 \%, \geq 8.0 \%$, or $\geq 9.0 \%$ after reaching the HbA1c target; (6) treatment failure, a novel composite outcome defined as the composite endpoint of HbAlc exceeding the target threshold or having a prescription for a non-index AHA; and (7) medication costs for continuous therapy with canagliflozin only in the canagliflozin $300 \mathrm{mg}$ cohort or with a GLP-1 receptor agonist only in the any dose GLP-1 receptor agonist cohort over 12 months.

\section{Statistical analysis}

To reduce the potential for treatment selection and confounding bias and allow the use of all patients in this study, the propensity score method with inverse probability of treatment weighting was used. The analysis was conducted in two phases. First, the probability of receiving canagliflozin $300 \mathrm{mg}$ or any dose of a GLP-1 receptor agonist was estimated using a logistic regression model. Next, absolute standardized differences were used to assess the balance of baseline covariates between the two cohorts. Inverse probability of treatment weights was calculated to normalize the inflated sample size. ${ }^{17}$ A standardized difference of $<10 \%$ after applying inverse probability of treatment weighting indicated well-balanced baseline covariates. ${ }^{18} 19$

Descriptive statistics (means and SDs for continuous variables, frequency and percentages for categorical variables) were provided for baseline demographic and clinical characteristics, and other study measures of interest. Student's (or unpaired) t-tests were used to compare mean HbAlc values between cohorts at 3-month intervals. Student's t-tests and $\chi^{2}$ tests were used to compare adherence and AHA initiation patterns in the canagliflozin $300 \mathrm{mg}$ and any dose GLP-1 receptor agonist cohorts. Cox proportional hazards models were used for multivariable regression analyses, and estimates were reported using HRs and 95\% CIs for achievement of HbA1c targets and treatment durability outcomes. Patients were followed from the index date until the first event of interest or censoring, whichever occurred first. Censoring was defined as the end of the follow-up time of 12 months if no event of interest was observed. All analyses were conducted using SAS Enterprise Guide V.7.15.

Medication costs for each cohort were calculated by totaling only the cost of canagliflozin $300 \mathrm{mg}$ or the GLP-1 receptor agonist at any dose that was paid by patients and the health plan for each cohort. The cost was reported only for patients who had $\mathrm{HbAlc}<8.0 \%$ (HEDIS quality measure) at any time from baseline through the follow-up period. Costs were discounted in 2017 dollar values according to data from the Bureau of Labor Statistics.

This manuscript was written in accord with the Reporting of Studies Conducted Using Observational Routinely Collected Health Data statement. ${ }^{20}$ 


\section{RESULTS}

\section{Baseline demographic and clinical characteristics}

Of the 76603 patients with T2DM and a claim for canagliflozin $300 \mathrm{mg}$ or any dose of a GLP-1 receptor agonist, a total of 3171 met all inclusion and exclusion criteria (755 initiated on canagliflozin $300 \mathrm{mg}$, and 2416 initiated on any dose of a GLP-1 receptor agonist; online supplementary figure 1). Prior to inverse probability of treatment weighting, patients initiated on canagliflozin
$300 \mathrm{mg}$ versus any dose of a GLP-1 receptor agonist were older (mean age 54.6 vs 53.1 years, standardized difference $17 \%$ ) and less likely to be female (38.0\% vs $52.9 \%$, standardized difference 30\%; table 1). Mean Elixhauser Comorbidity Index was lower for patients initiated on canagliflozin $300 \mathrm{mg}$ compared with patients initiated on any dose of a GLP-1 receptor agonist (3.17 vs 3.35, standardized difference $11 \%$ ). Patients initiated on canagliflozin $300 \mathrm{mg}$ were more likely to be treated with

Table 1 Demographic and clinical characteristics

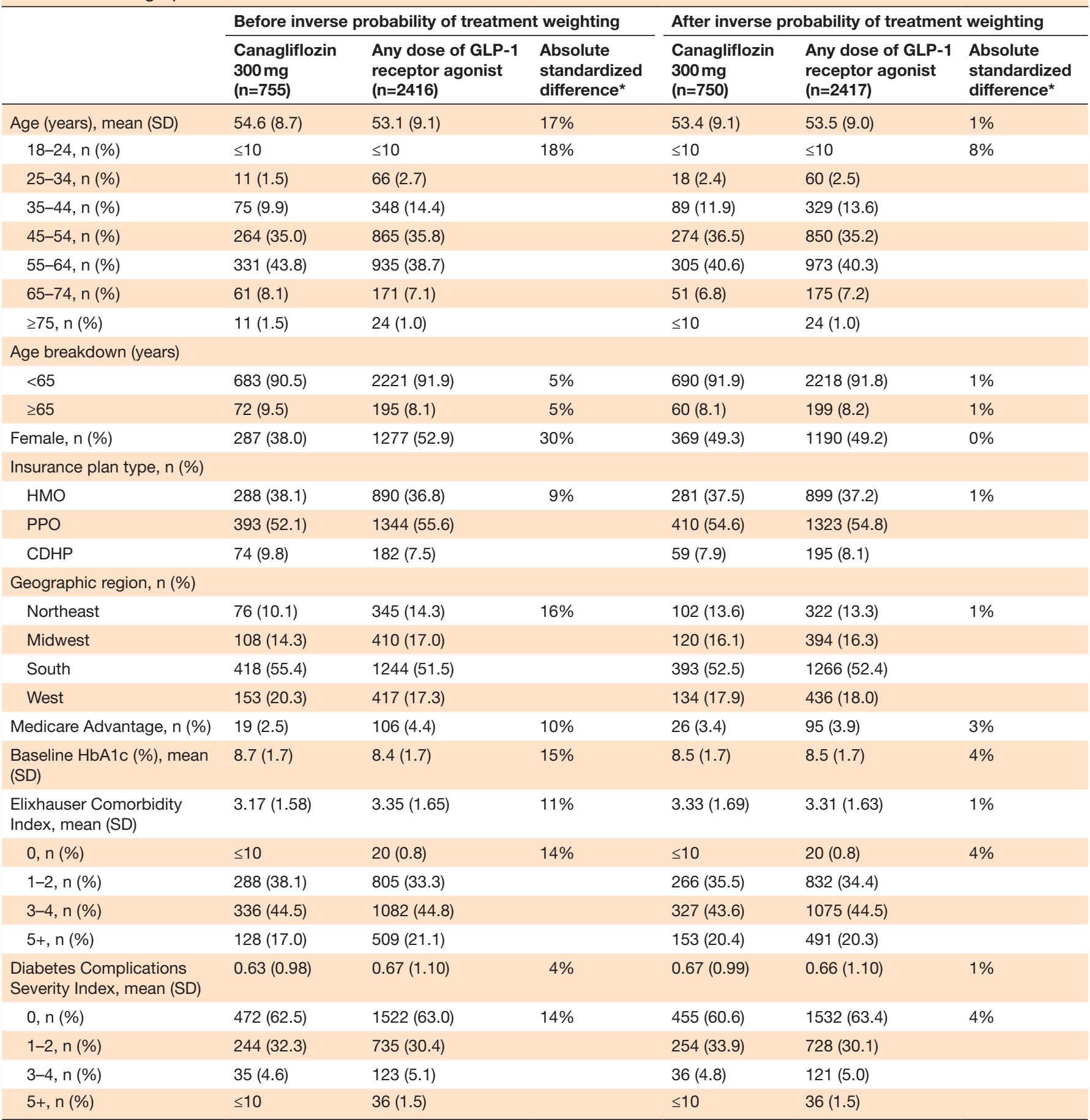

${ }^{*}$ Absolute standardized difference $>10 \%$ is considered significant.

CDHP, consumer-driven health plan (health reimbursement account, health savings account); GLP-1, glucagon-like peptide-1; HMO, health maintenance organization; PPO, preferred provider organization. 
sulfonylureas $(47.7 \%$ vs $37.3 \%$, standardized difference $21 \%$ ) or DPP-4 inhibitors (50.7\% vs $33.7 \%$, standardized difference $35 \%$ ) during the baseline period than those initiated on GLP-1 receptor agonists at any dose (online supplementary table 2). After inverse probability of treatment weighting, baseline demographic and clinical characteristics were well balanced in the canagliflozin $300 \mathrm{mg}$ and any dose GLP-1 receptor agonist cohorts (canagliflozin $300 \mathrm{mg}$ cohort: $\mathrm{n}=750$; any dose GLP-1 receptor agonist cohort: $\mathrm{n}=2417$; all standardized differences $<10 \%$; table 1 and online supplementary table 2 ). The mean (SD) baseline HbAlc values were similar in the canagliflozin $300 \mathrm{mg}(8.5 \%$ (1.67) ) and any dose GLP-1 receptor agonist cohorts (8.5\% (1.74); standardized difference $4 \%$ ).

\section{Change in HbA1c levels and target attainment}

Mean HbAlc levels over 12 months of follow-up, measured at 3-month intervals, were similar between the canagliflozin $300 \mathrm{mg}$ and any dose GLP-1 receptor agonist cohorts in the overall population (figure 1A) and regardless of baseline HbAlc $(7.0 \%$ to $<8.0 \%, 8.0 \%$ to $<9.0 \%$, and $\geq 9.0 \%$; figure $1 \mathrm{~B}$ ). Cox proportional hazards model estimates showed no difference in the achievement of $\mathrm{HbAlc}<8.0 \%$ in the canagliflozin $300 \mathrm{mg}$ and any dose GLP-1 receptor agonist cohorts $(51.9 \%$ vs $49.7 \%$; HR 1.04, 95\% CI 0.89 to $1.21 ; \mathrm{p}=0.666)$. Patients in the canagliflozin $300 \mathrm{mg}$ cohort were less likely to achieve HbA1c $<7.0 \%$ than those in the any dose GLP-1 receptor agonist cohort $(27.1 \%$ vs $30.4 \%$; HR $0.81,95 \%$ CI 0.68 to $0.96 ; \mathrm{p}=0.016$ ) and more likely to achieve $\mathrm{HbA1}<<9.0 \%$ (69.4\% vs $61.9 \%$; HR $1.24,95 \%$ CI 1.04 to 1.48 ; $\mathrm{p}=0.020$; figure 2).

\section{Adherence}

During the 12-month follow-up period, a greater proportion of patients in the canagliflozin $300 \mathrm{mg}$ cohort were adherent to the index medication (proportion of days covered $\geq 80 \%$ ) compared with those in the any dose GLP-1 receptor agonist cohort $(47.5 \%$ vs $37.5 \%$; $\mathrm{p}<0.0001$; table 2), with an average of $67 \%$ vs $59 \%$ days covered $(\mathrm{p}<0.0001)$ by the index medication.

\section{Treatment patterns}

A lower proportion of patients in the canagliflozin $300 \mathrm{mg}$ cohort switched AHA medications compared with those in the any dose GLP-1 receptor agonist cohort (33.8\% vs $38.4 \%$; $\mathrm{p}=0.023)$. Among those who switched medications, the average time to switch was longer in the canagliflozin $300 \mathrm{mg}$ cohort than the any dose GLP-1 receptor agonist cohort (198 vs 176 days; $\mathrm{p}=0.002$ ). Patients in the canagliflozin $300 \mathrm{mg}$ cohort most frequently switched to metformin $(15.5 \%)$, DPP-4 inhibitors $(8.9 \%)$, or sulfonylureas $(8.2 \%)$. In the any dose GLP-1 receptor agonist cohort, patients most frequently switched to metformin $(18.0 \%)$, insulin $(7.8 \%)$, or sulfonylureas $(7.5 \%)$.

In the 12 months after index, the proportion of patients in the canagliflozin $300 \mathrm{mg}$ and any dose GLP-1 receptor agonist cohorts who added on a new AHA medication $(32.6 \%$ and $33.1 \% ; \mathrm{p}=0.801)$ was not statistically different, as was mean time to initiation between cohorts ( 158 vs 160 days; $p=0.751$ ). A lower proportion of patients in the canagliflozin $300 \mathrm{mg}$ cohort had a new prescription for insulin (add-on and switch) compared with patients in the any dose GLP-1 receptor agonist cohort $(5.0 \%$ vs $8.1 \% ; \mathrm{p}=0.004)$.

The likelihood of discontinuation from the index medication was lower in the canagliflozin $300 \mathrm{mg}$ cohort than in the any dose GLP-1 receptor agonist cohort $(49.6 \%$ vs $57.4 \%$; HR $0.78,95 \%$ CI 0.70 to 0.88 ; $\mathrm{p}<0.0001$; table 2 ). Among those who discontinued the index medication, the mean time to discontinuation was longer in the canagliflozin $300 \mathrm{mg}$ cohort than the any dose GLP-1 receptor agonist cohort (187 vs 163 days; $\mathrm{p}=0.001$ ).

\section{Treatment durability}

The likelihood of HbA1c going above thresholds after having achieved them was not statistically different for patients in the canagliflozin $300 \mathrm{mg}$ and any dose GLP-1 receptor agonist cohorts for thresholds of $\mathrm{HbAlc} \geq 7.0 \%$ (HR 1.06, 95\% CI 0.82 to $1.38 ; \mathrm{p}=0.648$ ), HbAlc $\geq 8.0 \%$ (HR $0.96,95 \%$ CI 0.77 to $1.19 ; \mathrm{p}=0.716$ ), and $\mathrm{HbA} 1 \mathrm{c} \geq 9.0 \%$ (HR 0.79, 95\% CI 0.60 to 1.03 ; $\mathrm{p}=0.086$; figure 2 ).

The likelihood of treatment failure (defined as HbA1c going above threshold or having a prescription for a new AHA) was not statistically different for patients in the canagliflozin $300 \mathrm{mg}$ and any dose GLP-1 receptor agonist cohorts after achieving HbAlc $<7.0 \%$ (HR 1.05, $95 \%$ CI 0.87 to $1.28 ; \mathrm{p}=0.60$ ), HbAlc $<8.0 \%$ (HR 1.00, $95 \%$ CI 0.87 to $1.16 ; \mathrm{p}=0.96$ ), and $\mathrm{HbA} 1 \mathrm{c}<9.0 \%$ (HR 0.95 , $95 \%$ CI 0.82 to $1.10 ; \mathrm{p}=0.48)$.

\section{Cost analyses}

Medication costs for 1 year were $\$ 3218$ for patients in the canagliflozin $300 \mathrm{mg}$ cohort and $\$ 4639$ for patients in the any dose GLP-1 receptor agonist cohort. Thus, the mean annual medication costs were $\$ 1421$ less with canagliflozin $300 \mathrm{mg}$ versus any dose of a GLP-1 receptor agonist $(\mathrm{p}<0.001)$.

\section{DISCUSSION}

The current study, which used both claims and laboratory results from the HIRD, adds to the existing literature on the real-world effectiveness and costs related to treatment with canagliflozin $300 \mathrm{mg}$ versus GLP-1 receptor agonists at any dose in patients with T2DM. Our findings showed no significant differences in HbA1c levels over time (at 3-month intervals over 12 months) with canagliflozin $300 \mathrm{mg}$ and any dose of GLP-1 receptor agonists, as well as no significant difference in achieving secondary outcome of $\mathrm{HbAlc}<8.0 \%$, but a lower and higher likelihood of achieving $\mathrm{HbA} 1 \mathrm{c}<7.0 \%$ and $\mathrm{HbA} 1 \mathrm{c}<9.0 \%$, respectively, greater adherence, less discontinuation, and lower medication costs.

Although the recommended starting dose of canagliflozin is $100 \mathrm{mg},{ }^{21}$ approximately one-third of patients in 


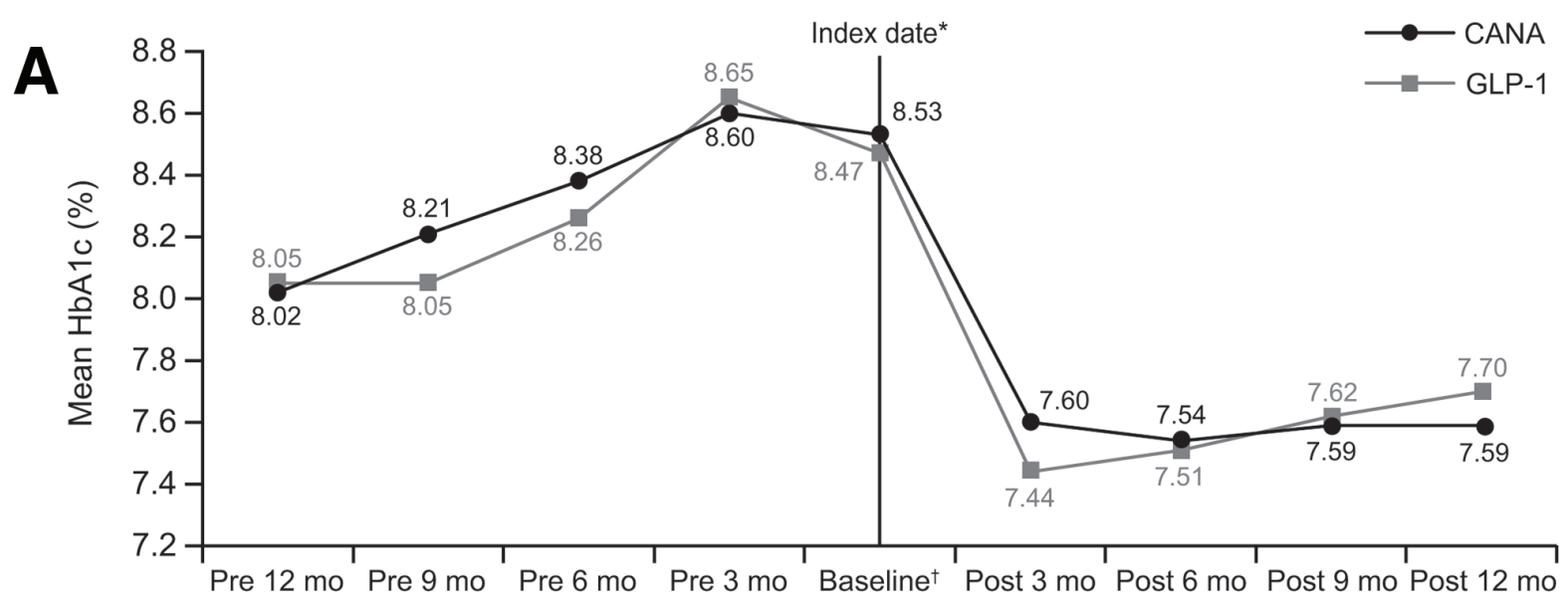

Number of patients with $\mathrm{HbA1c}$ measurements at each time point

Sample size

CANA $(n=750)$

GLP-1 $(n=2417)$

\begin{tabular}{|c|c|c|c|c|c|c|c|c|}
\hline \multicolumn{4}{|c|}{ Pre-index } & \multirow{2}{*}{$\begin{array}{l}\text { Index } \\
\text { date }\end{array}$} & \multicolumn{4}{|c|}{ Post-index } \\
\hline $12 \mathrm{mo}$ & $9 \mathrm{mo}$ & $6 \mathrm{mo}$ & $3 \mathrm{mo}$ & & $3 \mathrm{mo}$ & $6 \mathrm{mo}$ & $9 \mathrm{mo}$ & $12 \mathrm{mo}$ \\
\hline 303 & 312 & 355 & 555 & 750 & 362 & 387 & 373 & 375 \\
\hline 908 & 1002 & 1045 & 1862 & 2417 & 1027 & 1322 & 1198 & 1190 \\
\hline
\end{tabular}

B

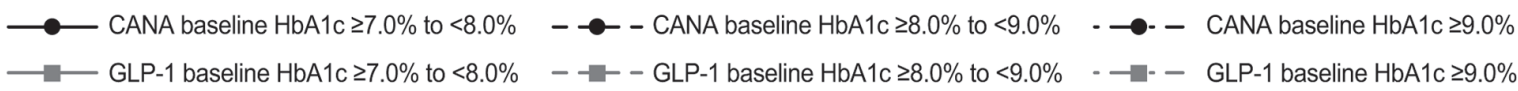

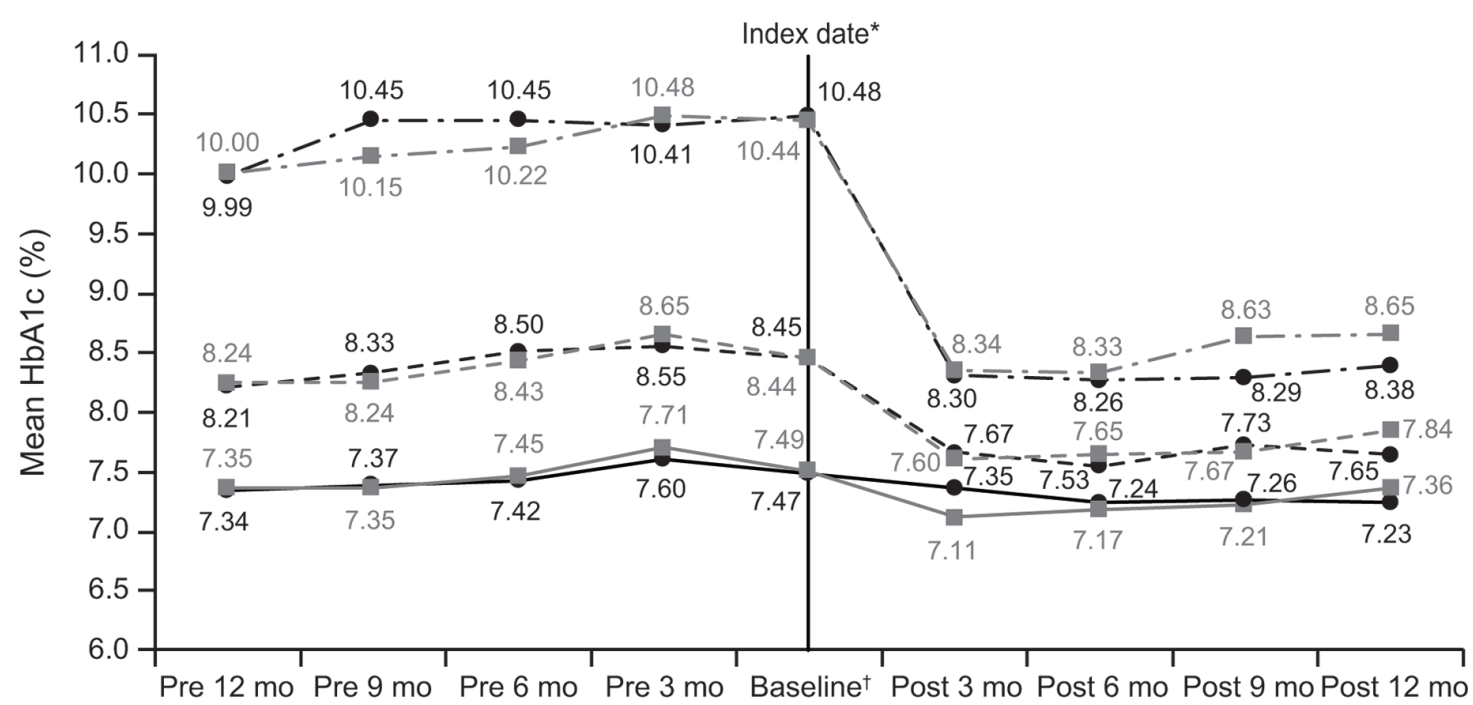

Number of patients with $\mathrm{HbA1c}$ measurements at each time point

\begin{tabular}{|c|c|c|c|c|c|c|c|c|c|}
\hline \multirow[b]{2}{*}{ Sample size } & \multicolumn{4}{|c|}{ Pre-index } & \multirow{2}{*}{$\begin{array}{c}\text { Index } \\
\text { date }\end{array}$} & \multicolumn{4}{|c|}{ Post-index } \\
\hline & $12 \mathrm{mo}$ & $9 \mathrm{mo}$ & $6 \mathrm{mo}$ & $3 \mathrm{mo}$ & & $3 \mathrm{mo}$ & $6 \mathrm{mo}$ & $9 \mathrm{mo}$ & $12 \mathrm{mo}$ \\
\hline \multicolumn{10}{|c|}{ Baseline $\mathrm{HbA} 1 \mathrm{c} \geq 7.0 \%$ to $<8.0 \%$} \\
\hline CANA $(n=229)$ & 111 & 120 & 125 & 169 & 229 & 106 & 119 & 123 & 114 \\
\hline GLP-1 ( $n=629)$ & 285 & 331 & 298 & 485 & 629 & 260 & 365 & 334 & 322 \\
\hline \multicolumn{10}{|c|}{ Baseline $\mathrm{HbA} 1 \mathrm{c} \geq 8.0 \%$ to $<9.0 \%$} \\
\hline CANA $(n=171)$ & 69 & 71 & 81 & 132 & 171 & 79 & 97 & 87 & 86 \\
\hline GLP-1 $(n=501)$ & 204 & 217 & 233 & 410 & 501 & 235 & 277 & 263 & 247 \\
\hline \multicolumn{10}{|c|}{ Baseline $\mathrm{HbA} 1 \mathrm{c} \geq 9.0 \%$} \\
\hline CANA $(n=243)$ & 71 & 76 & 99 & 180 & 243 & 120 & 119 & 114 & 116 \\
\hline GLP-1 $(n=819)$ & 239 & 253 & 307 & 638 & 819 & 334 & 434 & 390 & 391 \\
\hline
\end{tabular}

Figure 1 Mean HbA1c values at 3-month intervals in (A) the overall population and $(B)$ patients with baseline HbA1c between $7.0 \%$ and $<8.0 \%, 8.0 \%$ and $<9.0 \%$, and $\geq 9.0 \%$. (Student's t-test was used to analyze between-cohort differences at each time point.) *Date of initiation of CANA or GLP-1. ${ }^{\dagger}$ Last HbA1c value during 12 months before index date. CANA, canagliflozin 300 mg; GLP-1, any dose of a glucagon-like peptide-1 receptor agonist. 
$\mathrm{HR}(95 \% \mathrm{Cl})$

$p$ value

$\underline{\mathrm{HbA} 1 \mathrm{c} \text { target achievement }}$

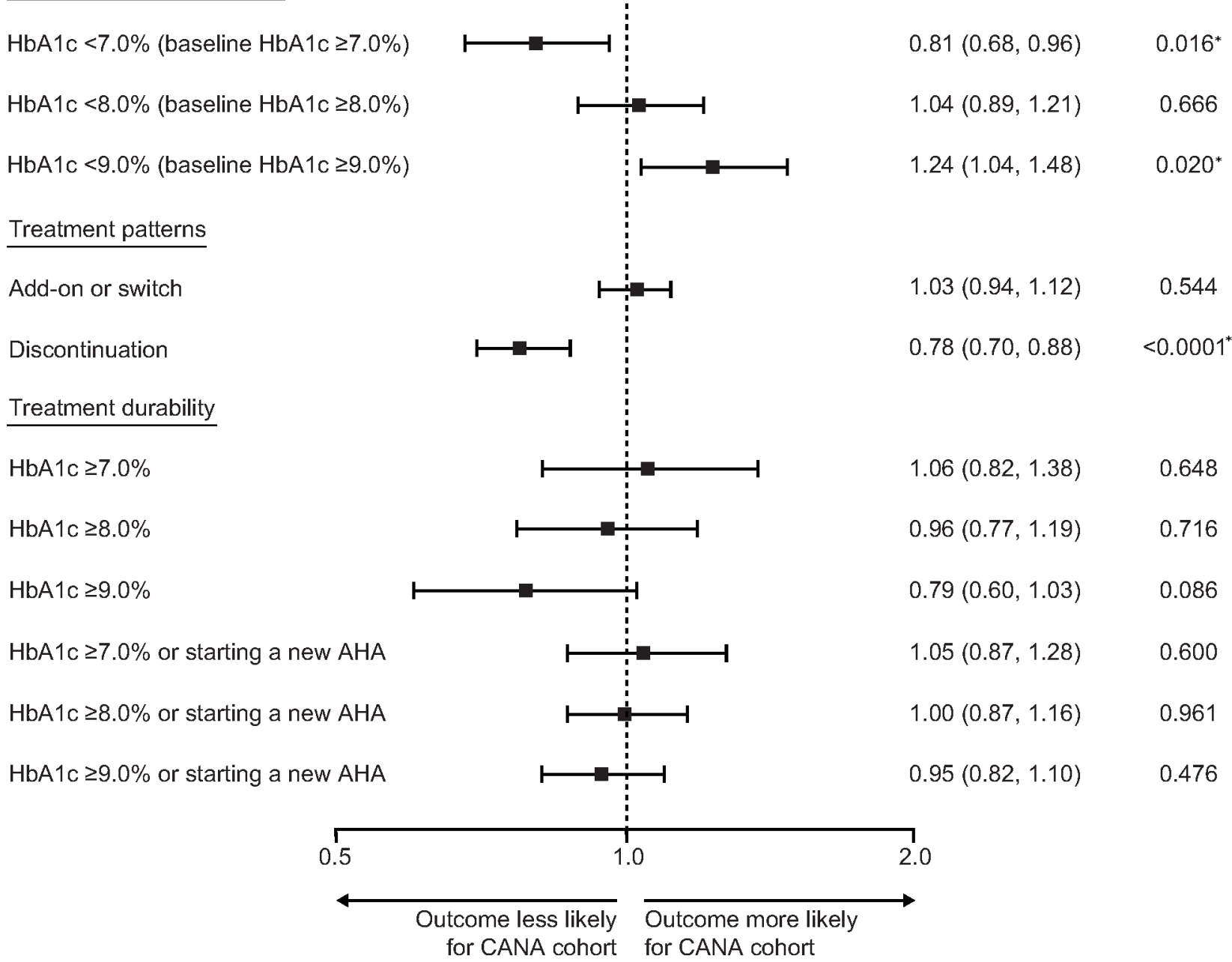

Figure 2 Achievement of HbA1c targets after initiation of canagliflozin $300 \mathrm{mg}$ or any dose of a GLP-1 receptor agonist and treatment failure and treatment patterns over 12 months of follow-up. *Statistically significant. AHA, antihyperglycemic agent; CANA, canagliflozin $300 \mathrm{mg}$; GLP-1, any dose of a glucagon-like peptide-1 receptor agonist.

the real world are initiated on canagliflozin $300 \mathrm{mg}$ and approximately two-thirds of patients are on canagliflozin $300 \mathrm{mg}$ within 9 to 12 months, reflecting widespread real-world use of canagliflozin $300 \mathrm{mg} .{ }^{22}{ }^{23}$ Findings from our study of claims and laboratory data showed similar patterns of HbAlc over time with canagliflozin $300 \mathrm{mg}$ and any dose of GLP-1 receptor agonists regardless of baseline HbA1c, which is consistent with previous realworld studies. ${ }^{13}{ }^{24-26}$ We found that at any time during follow-up, there was no difference in the likelihood of achieving HbAlc $<8.0 \%$ (HEDIS quality measure) with canagliflozin $300 \mathrm{mg}$ versus any dose of a GLP-1 receptor agonist. Patients were less likely to achieve HbAlc $<7.0 \%$ and more likely to achieve HbAlc $<9.0 \%$ with canagliflozin $300 \mathrm{mg}$. Some differences in HbAlc target attainment with canagliflozin $300 \mathrm{mg}$ and GLP-1 receptor agonists have been observed in a prior study. In that study, an analysis of the IQVIA Real-World Data EMR-US database found that patients initiated on canagliflozin $300 \mathrm{mg}$ versus a GLP-1 receptor agonist were less likely to achieve HbA1c $<7.0 \%$, but no differentiation was observed in achievement of $\mathrm{HbA} 1 \mathrm{c}<8.0 \%$ and $<9.0 \% .^{25} 26$ Differences in patient characteristics and sample size, the use of additional AHAs in intent-to-treat analyses and follow-up time across studies may explain some of the variation in the achievement of $\mathrm{HbA1c}<9.0 \%$.

A greater proportion of patients were adherent to treatment with canagliflozin $300 \mathrm{mg}$ versus any dose of a GLP-1 receptor agonist, as measured by the proportion of days covered, and, on average, patients in the canagliflozin $300 \mathrm{mg}$ cohort had more days covered by the index medication than those in the any dose GLP-1 receptor agonist cohort. The rate of discontinuation of index medication was lower with canagliflozin $300 \mathrm{mg}$ versus any dose of GLP-1 receptor agonists, and patients who discontinued index medication were treated longer with canagliflozin $300 \mathrm{mg}$ versus a GLP-1 receptor agonist at any dose before discontinuation. The greater adherence and lower rate of discontinuation seen with canagliflozin $300 \mathrm{mg}$ versus any dose of GLP-1 receptor agonists in this study are 
Table 2 Adherence and AHA initiation during 12 months of follow-up

\begin{tabular}{|c|c|c|c|}
\hline & $\begin{array}{l}\text { Canagliflozin } \\
300 \mathrm{mg}(\mathrm{n}=750)\end{array}$ & $\begin{array}{l}\text { Any dose of GLP-1 } \\
\text { receptor agonist }(n=2417)\end{array}$ & p value \\
\hline Proportion of days covered by index medication, $\mathrm{n}(\%)$ & $750(100.0)$ & $2417(100.0)$ & \\
\hline Proportion of days covered among all patients, mean (SD) & $0.67(0.29)$ & $0.59(0.31)$ & $<0.0001^{*}$ \\
\hline Proportion of days covered among all patients, median & 0.79 & 0.66 & \\
\hline Proportion of days covered <80\% (non-adherent), $\mathrm{n}(\%)$ & $394(52.5)$ & $1511(62.5)$ & $<0.0001^{*}$ \\
\hline Proportion of days covered $\geq 80 \%$ (adherent), $\mathrm{n}(\%)$ & $356(47.5)$ & $906(37.5)$ & \\
\hline Any new $\mathrm{AHA}, \mathrm{n}(\%)$ & $244(32.6)$ & $800(33.1)$ & 0.801 \\
\hline Time to new AHA from index date (days), mean (SD) & $158(110)$ & $160(109)$ & 0.751 \\
\hline Time to new AHA from index date (days), median & 146 & 148 & \\
\hline Discontinuation of the index medication, $\mathrm{n}(\%)$ & $372(49.6)$ & $1388(57.4)$ & $<0.0001^{*}$ \\
\hline Time to discontinuation (days), mean (SD) & $187(120)$ & $163(120)$ & $0.001^{*}$ \\
\hline Time to discontinuation (days), median & 182 & 127 & \\
\hline Any switching of the index medication, $\mathrm{n}(\%)$ & $253(33.8)$ & $928(38.4)$ & $0.023^{*}$ \\
\hline Time to the first switching (days), mean (SD) & $198(103)$ & $176(96)$ & $0.002^{*}$ \\
\hline Time to the first switching (days), median & 224 & 166 & \\
\hline \multicolumn{4}{|l|}{ Newly started AHAs after switching, $\mathrm{n}(\%) \dagger$} \\
\hline SGLT2 inhibitors & $20(2.7)$ & $68(2.8)$ & 0.835 \\
\hline GLP-1 receptor agonists & $27(3.6)$ & $85(3.5)$ & 0.950 \\
\hline Sulfonylureas & $62(8.2)$ & $181(7.5)$ & 0.523 \\
\hline Biguanides (metformin $\mathrm{HCl}$ ) & $116(15.5)$ & $435(18.0)$ & 0.115 \\
\hline DPP-4 inhibitors & $67(8.9)$ & $104(4.3)$ & $<0.0001^{*}$ \\
\hline Thiazolidinediones & $12(1.6)$ & $43(1.8)$ & 0.754 \\
\hline Insulin & $31(4.1)$ & $188(7.8)$ & $0.001^{*}$ \\
\hline Amylin analogs (pramlintide acetate) & $0(0.0)$ & $0(0.0)$ & - \\
\hline Alpha-glucosidase inhibitors & $0(0.0)$ & $0(0.0)$ & - \\
\hline Meglitinide analogs & $\leq 10$ & $\leq 10$ & 0.940 \\
\hline Others $\ddagger$ & $0.5(0.1)$ & $\leq 10$ & 0.875 \\
\hline
\end{tabular}

*Statistically significant.

†The medication classes may not be mutually exclusive because patients may have filled prescriptions in more than one class on the same day. ‡Dextrose, bromocriptine, diazoxide, glucagon, glucagon (rDNA), glucagon $\mathrm{HCl}(\mathrm{rDNA})$, glucose-vitamin $\mathrm{C}$, mifepristone (hyperglycemia), metformin $\mathrm{HCl}$ - dietary management product, aldose reductase inhibitors.

AHA, antihyperglycemic agent; DPP-4, dipeptidyl peptidase-4; GLP-1, glucagon-like peptide-1; SGLT2, sodium glucose co-transporter 2.

consistent with observations from prior real-world studies which showed greater adherence with canagliflozin 100 and $300 \mathrm{mg}$ versus a GLP-1 receptor agonist (medication possession ratio: $0.72-0.92$ vs $0.33-0.67$; proportion of days covered: $0.71-0.81$ vs $0.33-0.58$, respectively) and a $30 \%$ lower rate of discontinuation with canagliflozin $300 \mathrm{mg}$ versus a GLP-1 receptor agonist. ${ }^{26-28}$ A possible explanation for the better adherence to treatment with canagliflozin $300 \mathrm{mg}$ versus any dose of a GLP-1 receptor agonist may be its mode of administration (ie, oral vs injection). Medication acquisition costs could also play a role in adherence to treatment.

In the current study, we found that the proportion of patients adding a new AHA was not different between cohorts; however, more patients in the any dose GLP-1 receptor agonist cohort initiated insulin compared with the canagliflozin $300 \mathrm{mg}$ cohort. Furthermore, once patients achieved the glycemic target, those initiating canagliflozin $300 \mathrm{mg}$ versus any dose of a GLP-1 receptor agonist had a similar likelihood of treatment failure, defined as the composite outcome of the prescription of a new non-index AHA or having HbAlc above target. This is in contrast to a previous real-world analysis showing that a lower proportion of patients treated with canagliflozin $300 \mathrm{mg}$ versus a GLP-1 receptor agonist initiated a new AHA or failed treatment. ${ }^{26}$

Our real-world data suggest that treatment with canagliflozin $300 \mathrm{mg}$ versus any dose of a GLP-1 receptor agonist may be a suitable choice for achieving the triple aim of diabetes care (improving the patient experience of care, improving the health of populations, and reducing the cost of healthcar ${ }^{29}$ ). The results of this study highlight the potential impact of the lower adherence and persistence to GLP-1 receptor agonists as used in actual practice, as those on canagliflozin $300 \mathrm{mg}$ remained on treatment longer, with fewer add-on medications, and no differences in HbAlc reductions at 3-month intervals. Furthermore, the real-world glycemic effectiveness of 
canagliflozin $300 \mathrm{mg}$ versus any dose of a GLP-1 receptor agonist is potentially achieved with lower overall medication costs. This may be helpful to inform clinical decisions regarding the choice of AHA medications.

Our study was strengthened by the use of the HIRD, which contains fully adjudicated claims information on filled prescriptions and laboratory data for about onethird of patients with claims data. The current findings support those of a similar real-world study that showed no difference in $\mathrm{HbAlc}$ reductions and lower medication costs with canagliflozin $300 \mathrm{mg}$ versus GLP-1 receptor agonists (IQVIA Real-World Data Electronic Medical Records-US database), but with more accurate adherence and persistence data as adjudicated prescription information was used instead of electronic medical records data, which may overestimate adherence and persistence. ${ }^{13}$ Our study was also strengthened by the use of the propensity score method, which reduced the potential bias due to dissimilar patient populations by controlling for differences in baseline characteristics.

\section{Limitations}

Due to approval dates and sample sizes, this analysis focused on canagliflozin only and did not include other SGLT2 inhibitors. Another limitation is that patients were required to initiate canagliflozin $300 \mathrm{mg}$ rather than canagliflozin $100 \mathrm{mg}$, which is not consistent with the prescribing information. ${ }^{21}$ However, it is known that approximately one-third of patients in the real world are initiated on canagliflozin $300 \mathrm{mg} .{ }^{23}$ Furthermore, this study compared patients who initiated the highest dose of canagliflozin $(300 \mathrm{mg})$ with those who initiated any dose of a GLP-1 receptor agonist, as the patients may be comparable in terms of disease severity and prior line of therapy. Data from a previous real-world study comparing canagliflozin versus GLP-1 receptor agonists found that most outcomes were generally similar for patients initiated on canagliflozin $100 \mathrm{mg}$ (vs $300 \mathrm{mg}$ ) ${ }^{26}$ Additionally, a prescription claim does not ensure that the medication was taken as prescribed and does not reflect the potential for use of medication samples (ie, the use of canagliflozin $100 \mathrm{mg}$ samples prior to a prescription for canagliflozin $300 \mathrm{mg}$ ). Another limitation is that only $\sim 33 \%$ of the population in the HIRD had laboratory data, and these patients may not be representative of the overall database. Furthermore, because all patients were commercially insured or had Medicare Advantage insurance, these results may not be generalizable beyond the US managed care population. In addition, interpretation of the novel composite endpoint based on exceeding HbA1c targets and initiation of a new AHA may not fully capture all possible aspects that could be used to define treatment failure. Similar to other retrospective analyses, this study is subject to possible measurement (ie, diagnosis coding) errors and residual confounding for variables that may differentially impact outcomes but are not available for use in the inverse probability of treatment weighting balancing methods. Additionally, this study was designed to assess effectiveness and treatment durability; therefore, safety data, including hypoglycemia, were not available. Lastly, the cost-effectiveness analysis used nonrebate prices, and may not reflect the amount actually paid by patients and health systems.

\section{CONCLUSION}

This real-world, US-based study demonstrated that initiation of canagliflozin $300 \mathrm{mg}$ versus initiation of any dose of a GLP-1 receptor agonist resulted in no difference in HbAlc values up to 12 months after index at 3-month intervals, with no difference in achievement of $\mathrm{HbA} 1 \mathrm{c}<8.0 \%$, better achievement of $\mathrm{HbA} 1 \mathrm{c}<9.0 \%$, and worse achievement of $\mathrm{HbAlc}<7.0 \%$, but with better adherence, less discontinuation, and lower drug acquisition costs when fully adherent in patients with T2DM.

\section{Author affiliations}

${ }^{1}$ HealthCore, Wilmington, Delaware, USA

${ }^{2}$ University of Connecticut School of Pharmacy, Storrs, Connecticut, USA

${ }^{3}$ Janssen Scientific Affairs, LLC, Titusville, New Jersey, USA

Acknowledgements The authors would like to thank Jennifer Cai, MS, MPH, for her contributions to this study. Medical writing support was provided by Dana Tabor, PhD, of MedErgy, and was funded by Janssen Scientific Affairs, LLC.

Contributors MS, $\mathrm{HT}$, and CN contributed to study design, data analysis and interpretation, and manuscript development. $\mathrm{CIC}, \mathrm{MH}$, and $\mathrm{MI}$ contributed to study design, data interpretation, and manuscript development. All authors approved the final manuscript for submission.

Funding This work was supported by Janssen Scientific Affairs, LLC. Canagliflozin has been developed by Janssen Research \& Development, LLC, in collaboration with Mitsubishi Tanabe Pharma Corporation.

Competing interests MS, $\mathrm{HT}$, and $\mathrm{CN}$ are employees of HealthCore, which received funding from Janssen Scientific Affairs, LLC, to conduct this study. CIC has received research support from Janssen Pharmaceuticals, Inc., Bayer AG, and Boehringer Ingelheim Pharmaceuticals, Inc. MH and Ml are employees of Janssen Scientific Affairs, LLC.

Patient consent for publication Not required.

Provenance and peer review Not commissioned; externally peer reviewed. Data availability statement No data are available.

Open access This is an open access article distributed in accordance with the Creative Commons Attribution Non Commercial (CC BY-NC 4.0) license, which permits others to distribute, remix, adapt, build upon this work non-commercially, and license their derivative works on different terms, provided the original work is properly cited, appropriate credit is given, any changes made indicated, and the use is non-commercial. See: http://creativecommons.org/licenses/by-nc/4.0/.

ORCID iD

Michael Ingham http://orcid.org/0000-0001-9462-9165

\section{REFERENCES}

1 American Diabetes Association. Standards of medical care in diabetes - 2018. Diabetes Care 2018;41:S1-159.

2 Fallon Health. Healthcare effectiveness data and information set (HEDIS ${ }^{\circledR}$ ) measures, 2018. Available: http://www.fchp.org/providers/ resources/hedis-measures.aspx [Accessed 5/1/18].

3 Garber AJ, Abrahamson MJ, Barzilay JI, et al. Consensus Statement by the American Association of Clinical Endocrinologists and American College of Endocrinology on the Comprehensive Type 2 Diabetes Management Algorithm - 2018 Executive Summary. Endocr Pract 2018;24:91-120.

4 Neal B, Perkovic V, Mahaffey KW, et al. Canagliflozin and cardiovascular and renal events in type 2 diabetes. N Engl J Med 2017;377:644-57. 
5 Zinman B, Wanner C, Lachin JM, et al. Empagliflozin, cardiovascular outcomes, and mortality in type 2 diabetes. $N$ Engl $\mathrm{J} \mathrm{Med}$ 2015;373:2117-28.

6 Marso SP, Daniels GH, Brown-Frandsen K, et al. Liraglutide and cardiovascular outcomes in type 2 diabetes. $N$ Engl $J$ Med 2016;375:311-22.

7 Mearns ES, Sobieraj DM, White CM, et al. Comparative efficacy and safety of antidiabetic drug regimens added to metformin monotherapy in patients with type 2 diabetes: a network metaanalysis. PLoS One 2015;10:e0125879.

8. Taieb V, Pacou M, Schroeder M, et al. A network meta-analysis $(\mathrm{NMa})$ to assess the longer-term relative efficacy of canagliflozin in patients with type 2 diabetes inadequately controlled on metformin. Value in Health 2015;18.

9. Taieb V, Pacou M, Schroeder M, et al. Bayesian network metaanalysis (NMa) to assess the relative efficacy of canagliflozin in patients with type 2 diabetes mellitus (T2DM) inadequately controlled with insulin. Value in Health 2015;18.

10. Van Sanden S, Diels J, Guillon P, et al. Bayesian network metaanalysis (NMa) to assess relative efficacy of canagliflozin (CANA) versus glucagon-like peptide-1 (GLP-1) agonists in dual and triple therapy in patients with type 2 diabetes mellitus (T2DM). Value in Health 2015;18.

11 Zaccardi F, Webb DR, Htike ZZ, et al. Efficacy and safety of sodiumglucose co-transporter-2 inhibitors in type 2 diabetes mellitus: systematic review and network meta-analysis. Diabetes Obes Metab 2016;18:783-94.

12 Rosenthal N, Meininger G, Ways K, et al. Canagliflozin: a sodium glucose co-transporter 2 inhibitor for the treatment of type 2 diabetes mellitus. Ann N Y Acad Sci 2015;1358:28-43.

13 Wysham $\mathrm{CH}$, Pilon D, Ingham M, et al. HbA1c control and costeffectiveness in patients with type 2 diabetes mellitus initiated on canagliflozin or a glucagon-like peptide 1 receptor agonist in a realworld setting. Endocr Pract 2018;24:273-87.

14 Elixhauser A, Steiner C, Harris DR, et al. Comorbidity measures for use with administrative data. Med Care 1998;36:8-27.

15 Young BA, Lin E, Von Korff M, et al. Diabetes complications severity index and risk of mortality, hospitalization, and healthcare utilization. Am J Manag Care 2008;14:15-23.

16 Peterson AM, Nau DP, Cramer JA, et al. A checklist for medication compliance and persistence studies using retrospective databases. Value in Health 2007;10:3-12.

17 Xu S, Ross C, Raebel MA, et al. Use of stabilized inverse propensity scores as weights to directly estimate relative risk and its confidence intervals. Value in Health 2010;13:273-7.
18 Austin PC. An introduction to propensity score methods for reducing the effects of confounding in observational studies. Multivariate Behav Res 2011;46:399-424.

19 Normand ST, Landrum MB, Guadagnoli E, et al. Validating recommendations for coronary angiography following acute myocardial infarction in the elderly: a matched analysis using propensity scores. J Clin Epidemiol 2001;54:387-98.

20 Benchimol El, Smeeth L, Guttmann A, et al. The REporting of studies Conducted using Observational Routinely-collected health Data (RECORD) statement PLoS Med 2015;12:e1001885.

21 INVOKANA® (canagliflozin) tablets, for oral use [package insert]. Titusville, NJ: Janssen Pharmaceuticals, 2018.

22 Buysman EK, Chow W, Henk HJ, et al. Characteristics and shortterm outcomes of patients with type 2 diabetes mellitus treated with canagliflozin in a real-world setting. Curr Med Res Opin 2015;31:137-43.

23 Buysman EK, Anderson A, Bacchus S, et al. Retrospective study on the impact of adherence in achieving glycemic goals in type 2 diabetes mellitus patients receiving canagliflozin. Adv Ther 2017;34:937-53.

24 Wysham C, Pilon D, Ingham M, et al. Glycemic control and treatment costs in patients with type 2 diabetes mellitus initiated on canagliflozin $300 \mathrm{mg}$ or a glucagon-like peptide-1 receptor agonist in a real-world setting. Poster presented at the 77th Scientific Sessions of the American Diabetes Assosciation (ADA); June 9-13, 2017. San Diego, CA.

25 Wysham C, Pilon D, Ingham M, et al. Real-World HbA1c levels in the context of persistence, treatment progression, and durability of $\mathrm{HbA1c}$ control in patients with type 2 diabetes mellitus initiated on canagliflozin or a glucagon-like peptide-1 receptor agonist. Poster presented at the 26th Annual Scientific and Clinical Congress of the American Association of Clinical Endocrinologists (AACE); May 3-7, 2017. Austin, TX.

26 Wysham $\mathrm{CH}$, Pilon D, Ingham M, et al. Quality goal attainment and maintenance in patients with type II diabetes mellitus initiated on canagliflozin or a glucagon-like peptide- 1 receptor agonist in an actual practice setting. Curr Med Res Opin 2018;34:1125-33.

27 Cai J, Divino V, Burudpakdee C. Adherence and persistence in patients with type 2 diabetes mellitus newly initiating canagliflozin, dapagliflozin, DPP-4s, or GLP-1s in the United States. Curr Med Res Opin 2017;33:1317-28.

28 Cai J, Wang Y, Baser O, et al. Comparative persistence and adherence with newer anti-hyperglycemic agents to treat patients with type 2 diabetes in the United States. J Med Econ 2016;19:1175-86.

29 Berwick DM, Nolan TW, Whittington J. The triple aim: care, health, and cost. Health Aff (Millwood) 2008;27:759-69. 